\title{
ANALISIS KEMAMPUAN PENALARAN ANALOGIS MAHASISWA PENDIDIKAN MATEMATIKA DALAM PERSAMAAN DIFERENSIAL ORDO SATU
}

\author{
Sendi Ramdhani \\ FKIP Universitas Suryakancana, Cianjur \\ sendi@unsur.ac.id
}

\begin{abstract}
ABSTRAK
Tujuan penelitian ini untuk mendeskripsikan kemampuan penalaran analogis mahasiwa pendidikan matematika dan kesulitan yang dihadapi mahasiwa pendidikan matematika dalam menyelesaikan soal-soal kemampuan penalaran analogis. Penelitian ini dilaksanakan dengan metode penelitian deskriftif kualitatif dimana peneliti melakukan analisis mendalam terhadap kemampuan penalaran analogis mahasiswa berdasarkan jawaban tes yang diberikan. Penelitian ini dilakukan pada 32 Mahasiswa Program Studi Pendidikan Matematika Universitas Suryakancana tahun pelajaran 2016-2017. Dari hasil penelitian ini diketahui bahwa: 1) Kemampuan penalaran analogis mahasiswa pendidikan matematika berada pada kategori sangat kurang pada dua soal, yaitu yang berkaitan dengan menentukan solusi umum dari sebuah persamaan diferensial ordo satu homogen dan menentukan solusi khusus dari sebuah persamaan diferensial ordo satu peubah terpisah. Kemudian pada kategori kurang pada dua soal, yaitu yang berkaitan dengan memeriksa sebuah persamaan adalah solusi khusus dari persamaan diferensial ordo satu. Sedangkan berada pada kategori baik pada tiga soal, yaitu menentukan solusi umum dari persamaan diferensial ordo satu eksak dan linear, serta menentukan faktor integrasi; 2) Kesulitan mahasiswa yang dihadapi pada mengidentifikasi skema dasar bentuk persamaan diferensial ordo satu peubah terpisah dan homogen dan langkah-langkah penyelesaian yang dianggap rumit sehingga ketika berhadapan dengan skema baru mereka kesulitan. Kemudian juga yang terkaitan dengan menentukan solusi khusus dan memeriksa bahwa sebuah persamaan adalah solusi khusus dari sebuah persamaan diferensial, karena berhubungan dengan persamaan diferensial ordo satu peubah terpisah.
\end{abstract}

Kata Kunci: Penalaran Analogis, Mahasiwa, Persamaan Diferensial Ordo Satu

\section{PENDAHULUAN}

Berpikir, bernalar, dan berargumentasi sangat penting dan sangat sering digunakan di dalam kehidupan nyata sehari-hari, di dalam mata pelajaran matematika sendiri maupun mata pelajaran lainnya (Shadiq, 2013). Kemampuan penalaran merupakan komponen penting dari pendidikan, dan kemampuan penalaran diperlukan untuk memahami matematika khususnya, dan mengembangkan ide-ide (National Council of Teachers of Mathematics [NCTM], 2000). Kemampuan penalaran dapat membantu siswa untuk memahami dan mengevaluasi karena penalaran sangat efektif bagi kemampuan siswa dalam menganalisis situasi baru yang dihadapi dalam semua aspek. Kemampuan penalaran juga bermanfaat dalam membuat asumsi logis, menjelaskan pikiran mereka, mencapai 
kesimpulan dan mempertahankan kesimpulan mereka (Mofidi dkk, 2012). Penalaran terdiri dari tiga jenis, yaitu penalaran induksi, penalaran deduksi, dan penalaran analogis (Mofidi dkk, 2012).

Penalaran analogis adalah salah satu aspek yang paling penting dalam pemikiran matematis. Sayangnya itu digunakan dalam ukuran yang sangat rendah dalam pendidikan" (Marcus dalam Magdaş, 2015). Penalaran analogis juga adalah pusat kemampuan kognitif yang digunakan dalam kehidupan kita sehari-hari (Haglund, 2012). Guru matematika seharusnya mendorong siswa untuk mengidentifikasi dan menggunakan analogical reasoning sebanyak mungkin dalam berbagai konteks (Magdaş, 2015).

Penalaran analogis mengembangkan kemampuan untuk menemukan aspek serupa yang dikenal dalam situasi baru, kemampuan untuk menerapkan hal-hal yang dikenal dalam situasi baru, kemampuan menggeneralisasi. Analogi sebagai metode khusus dalam matematika memiliki banyak manfaat tidak hanya matematika tetapi juga dalam kegiatan kehidupan nyata (Magdaş, 2015). Analogi merupakan salah satu strategi yang digunakan untuk membantu siswa dengan membangun pengetahuan konseptual. Analogi memungkinkan siswa untuk menerapkan kesamaan antara hubungan matematis untuk membantu memahami masalah baru atau konsep melalui kontribusi komponen integral dari kemampuan matematika (Mofidi dkk, 2012).

Mahasiswa pendidikan matematika tentunya harus memiliki kemampuan penalaran analogis, selain akan menghadapi berbagai mata kuliah-mata kuliah matematika, dimana salah satu aspek yang paling penting dalam pemikiran matematis. Mahasiswa pendidikan matematika juga sebagai calon guru matematika harus mengembangkan pembelajaran yang dapat meningkatkan kemampuan penalaran analogis karena analogi dapat membantu siswa membangun pengetahuan konseptual.

\section{Penalaran}

Penalaran didefinisikan sebagai tindakan menggunakan alasan untuk mengambil kesimpulan dari beberapa premis (Mofidi dkk, 2012). Penalaran atau reasoning (dalam bahasa Inggris) merupakan penggunaan akal dalam penarikan kesimpulan atau menyimpulkan berdasarkan akal (merriam-webster, Tanpa Tahun). Penalaran atau reasoning juga didefinisikan sebagai kemampuan akal untuk berpikir dan memahami halhal dengan cara yang logis (Merriam-Webster Learner's Dictonary, Tanpa Tahun). Sedangkan 
menurut Kamus Besar Bahasa Indonesia (Tanpa Tahun), penalaran adalah proses mental dalam mengembangkan pikiran dari beberapa fakta atau prinsip.

Kemampuan penalaran merupakan komponen penting dalam pendidikan, dan kemampuan penalaran diperlukan untuk memahami matematika khususnya, dan juga merupakan sarana penting untuk mengembangkan ide-ide (National Council of Teachers of Mathematics, 2000). Penalaran matematis mengacu pada kemampuan untuk merumuskan dan merepresentasikan masalah matematika yang diberikan, serta untuk menjelaskan dan menjustifikasi solusi atau argumen (Kilpatrick, Swafford \& Findell, 2001).

\section{Analogi}

Analogi adalah perbandingan antara hal-hal yang memiliki fitur serupa, sering juga digunakan untuk menjelaskan prinsip atau ide (Cambridge Dictionary, Tanpa Tahun). Analogi juga didefinisikan menyimpulkan dari dua atau lebih hal-hal yang sama satu sama lain atau dalam beberapa hal sama, kemiripan dalam beberapa hal khusus antara hal-hal lain seperti: kesamaan perbandingan berdasarkan kemiripan (merriam-webster). Sedangkan dalam Kamus Besar Bahasa Indonesia, analogi adalah persamaan atau persesuaian antara dua benda atau hal yang berlainan; sesuatu yang sama dalam bentuk, susunan, atau fungsi, tetapi berlainan asal-usulnya sehingga tidak ada hubungan kekerabatan; kesamaan sebagian ciri antara dua benda atau hal yang dapat dipakai untuk dasar perbandingan (Kamus Besar Bahasa Indonesia, Tanpa Tahun).

Analogi adalah hubungan kesamaan antara dua domain, dimana domain yang satu adalah representasi tetap dari aspek-aspek tertentu dari fenomena, situasi, proses, model, masalah, struktur konseptual, dan lain-lain yang relevan untuk analogi tertentu (Schlimm, 2008).

Menurut Polya bagian penting dari penemuan matematika terdiri dari klarifikasi analogi, yang awalnya sering tidak jelas dan ambigu, dan dia menyebutkan tiga jenis klarifikasi yang mungkin. Pertama, analogi dapat didasarkan pada "hubungan yang berdasarkan oleh aturan atau hukum yang sama," sebagai contoh dia menyebutkan analogi antara penambahan dan perkalian bilangan, karena keduanya bersifat komutatif, asosiatif, dan mengakui hubungan terbalik (invers). Sesuai dengan pendekatan aksiomatis terhadap analogi, Polya menyimpulkan bahwa "pada umumnya, sistem objek yang tunduk pada 
aturan atau hukum fundamental yang sama (atau aksioma) dapat dianggap analog satu sama lain, dan analogi semacam ini memiliki arti yang sama sekali jelas." Kedua, Sebuah isomorfisma, yang dipahami sebagai "korespondensi satu-satu yang mempertahankan hukum hubungan-hubungan tertentu" memberikan "analogi yang benar-benar diklarifikasi," sementara jenis analogi ketiga dijelaskan oleh homomorfisme, yang oleh Polya digambarkan sebagai "Secara sistematis menjabarkan terjemahan "di mana selukbeluk mungkin tersesat, tapi dimana semua yang asli menemukan representasi dan hubungan dipelihara dalam skala yang berkurang.. Dengan demikian, Polya menyebutkan baik seperangkat hukum atau aksioma umum, dan pemetaan struktur-melestarikan sebagai sarana untuk membuat analogi menjadi tepat (Schlimm, 2008).

\section{Penalaran Analogis}

Beberapa hal yang termasuk dalam penalaran analogis, adalah memperhatikan informasi yang relevan, mengekstrak hubungan di dalam dan lintas item, dan membuat pemetaan yang tepat di seluruh domain untuk menghasilkan kesimpulan dan/ atau mendapatkan prinsip umum (Holyoak, 2012).

Dua sistem dalam struktur seseorang kognitif: (a) sistem simbolik, dan (b) sistem penalaran asosiatif. Sistem penalarn simbolik atau berdasarkan aturan adalah di mana abstraksi masalah dunia nyata melalui representasi simbolis dan aturan. Asosiatif, sistem penalaran berbasis kesamaan adalah dimana masalah-masalah melalui asosiasi atau kemiripan dengan informasi lain yang dikenal (Daugherty dan Mentzer, 2008).

Penalaran analogis adalah fungsi sistem penalaran berbasis asosiatif. Jenis penalaran ini adalah metode untuk mengaktifkan skema yang tersimpan berdasarkan identifikasi koneksi, persamaan, atau kesamaan antara, yang biasanya dianggap sebagai Item yang berbeda. Analogi berfungsi sebagai jenis perancah, dimana informasi baru dilabuhkan pada schemata yang ada. Oleh karena itu, penalaran analogis menggunakan analog skema, atau pengetahuan dari pengalaman sebelumnya, untuk memfasilitasi pembelajaran dalam situasi baru (Ball, et al., 2004; Cross, 1994).

Pemetaan struktur adalah teori yang menjelaskan penalaran analogis. Teori pemetaan struktur mengemukakan bahwa skema analog dapat dipandang serupa dengan struktur relasional atau bagaimana kaitannya. Dengan kata lain, analogi adalah identifikasi aspek-aspek tertentu dari satu item (disebut sebagai domain yang dikenal atau dasar), 
serupa dengan aspek-aspek tertentu dari item lain (domain yang tidak diketahui atau target). Domain dasar dan domain target tidak serupa di semua akun, namun melalui struktur pemetaan struktur relasional dasar dan domain target ditemukan serupa (Gentner \& Gentner, 1983). Pemetaan struktur memungkinkan penyusunan skema baru berdasarkan kesimpulan dan prediksi. Kesimpulannya mengalami transformasi sehingga kedua item tersebut cukup dekat untuk memungkinkan pemetaan dan pemindahan dari basis ke target (Goldschmidt, 2001). Kausalitas kemudian dapat disimpulkan dan model mental kausal atau skema dikembangkan.

\section{METODE PENELITIAN}

Penelitian ini berusaha menggambarkan kemampuan penalaran analogis mahasiswa pendidikan matematika dalam menyelesaikan soal persamaan diferensial ordo satu, sehingga termasuk penelitian deskriptif kualitatif. Penelitian kualitatif cenderung menggunakan analisis dengan pendekatan induktif. Pemanfaatan teori-teori dan hasil kajian penelitian terdahulu yang relevan sebagai pisau analisis data kualitatif dapat menghasilkan deskripsi yang berbobot dengan makna yang mendalam (Darsinah dkk, 2013). Penelitian ini dilakukan dengan menganalisis dokumen yang berusaha menggambarkan kemampuan mahasiswa matematika dalam menyelesaikan soal persamaan diferensial ordo satu.

Adapun subjek penelitian ini adalah Mahasiswa Tingkat 3 kelas A Program Studi Pendidikan Matematika FKIP Universitas Suryakancana. Adapun jumlah mahasiswa tingkat 3 kelas B berjumlah 32 orang. Pertimbangan Mahasiswa Tingkat 3 kelas B Program Studi Pendidikan Matematika FKIP Universitas Suryakancana, yaitu: 1) Mata Kuliah Persamaaan Diferensial terdapat di Tingkat 3; 2) Mahasiswa Program Studi Pendidikan Matematika FKIP Universitas Suryakancana adalah calon guru matematika; 3) Kemampuan penalaran analogis masih belum optimal dikembangkan.

Analisis data dilakukan dengan menginvestigasi hasil tes. Adapun analisis yang dilakukan sebagai berikut,

$$
P=\frac{f}{N} \%
$$

Di mana: 
$\mathrm{P}=$ Angka persentase

$\mathrm{f}=$ Frekuensi yang sedang dicari persentasenya

$\mathrm{N}=$ Number of Casses (Jumlah frekuensi/banyaknya individu)

Untuk mengkategorikan kualitas kemampuan mahasiswa, peneliti menggunakan penilaian skala lima dan Tabel konversi sebagai berikut:

$\begin{array}{ll}85 \% \leq A \leq 100 \% & \text { Sangat Tinggi } \\ 70 \% \leq B<85 \% & \text { Tinggi } \\ 60 \% \leq C<75 \% & \text { Cukup } \\ 50 \% \leq D<60 \% & \text { Rendah } \\ 00 \% \leq E<50 \% & \text { Sangat Rendah }\end{array}$

(Suherman dan Sukjaya, 1990)

\section{HASIL PENELITIAN DAN PEMBAHASAN}

Berikut ini persentase kategori kemampuan mahasiswa berdasarkan nomor 1, nomor 2 , nomor 3 , nomor 4 , nomor 5 , nomor 6 , nomor 7 pada gambar 3 .

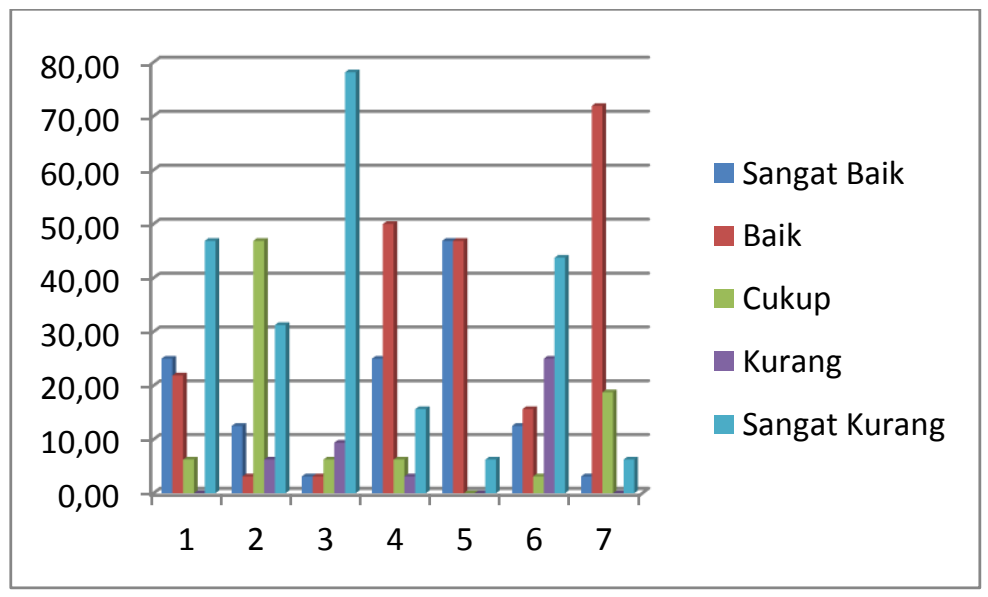

\section{Gambar 1. Diagram Batang Persentase Kategori Kemampuan Mahasiswa}

Berdasarkan diagram di atas kategori sangat baik paling tinggi dicapai mahasiswa pada soal no 5 yaitu 46,88\% sedangkan yang paling rendah adalah pada no 3 dan no 7 yaitu 3,13\%. Adapun kategori baik paling tinggi dicapai mahasiswa pada soal no 7 yaitu $71,88 \%$ sedangkan yang paling rendah adalah pada no 2 dan no 3 yaitu 3,13\%. Kemudian kategori cukup paling tinggi dicapai mahasiswa pada soal no 2 yaitu 46,88\% sedangkan yang paling rendah adalah pada no 6 yaitu 3,13\%. Selanjutnya kategori kurang paling tinggi pada soal no 6 yaitu 25\% sedangkan yang paling rendah adalah pada no 1 dan no 5 
yaitu $0 \%$.Sedangkan kategori sangat kurang paling tinggi pada soal no 3 yaitu $78,13 \%$ sedangkan yang paling rendah adalah pada no 5 dan no 7 yaitu $6,25 \%$.

Adapun rata-rata kemampuan mahasiswa setiap nomor soal dapat dilihat pada gambar 2.,

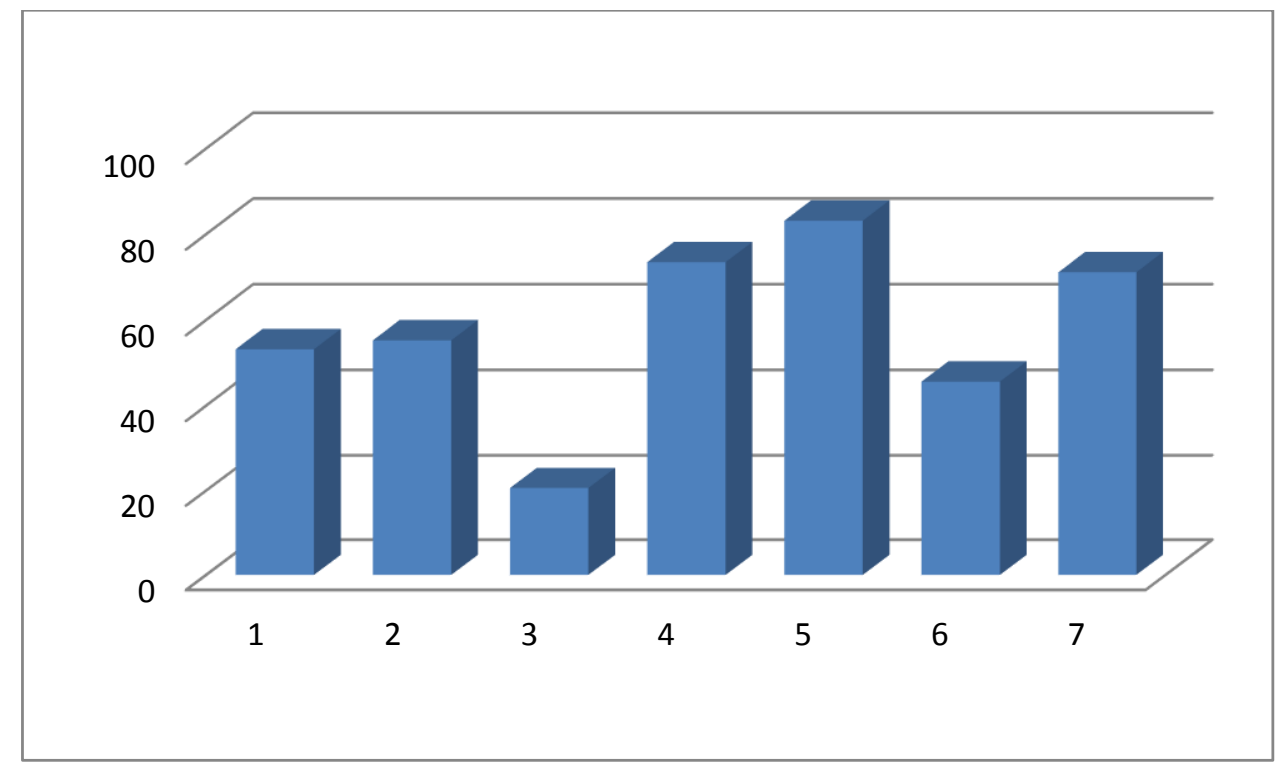

Gambar 2. Diagram Batang Rata-rata Setiap Nomor Soal

Berdasarkan gambar 2. dapat dilihat dari rata-ratanya no 5 paling tinggi dan no 3 paling rendah. No. 5 rata-rata pencapaian mahasiswa adalah 83,125 dan no 3 dengan ratarata 20,57 .

Berdasarkan rumusan masalah dalam bagian pembahasan ini akan dibahas dua poin yaitu kemampuan penalaran analogis mahasiswa program studi pendidikan matematika, dan kesulitan-kesulitan yang dihadapi mahasiswa.

\section{Kemampuan Penalaran Analogis Mahasiwa Pendidikan Matematika}

Berdasarkan rata-rata kemampuan mahasiswa dalam menjawab nomor satu yang berkaitan dengan memeriksa suatu persamaan merupakan solusi khusus dari sebuah persamaan diferensial, yaitu 53,125 dapat disimpulkan bahwa kemampuan mahasiswa berada pada kategori kurang. $47 \%$ yang berada dalam kategori sangat baik dan baik sedangkan $47 \%$ lainnya berada dalam kategori sangat kurang dan kurang, sisanya $6 \%$ cukup. 
Adapun rata-rata kemampuan mahasiswa dalam menjawab nomor dua yang berkaitan dengan menentukan suatu solusi umum persamaan diferensial ordo satu peubah terpisah, yaitu 55,208 dapat disimpulkan bahwa kemampuan mahasiswa berada pada kategori kurang. Hanya 16\% yang berada dalam kategori sangat baik dan baik sedangkan $37 \%$ lainnya berada dalam kategori sangat kurang, dan kurang, 47\% lainnya berada dalam kategori cukup.

Kemudian rata-rata kemampuan mahasiswa dalam menjawab nomor tiga yang berkaitan dengan menentukan suatu solusi umum persamaan diferensial ordo satu homogen, yaitu 20,573 dapat disimpulkan bahwa kemampuan mahasiswa berada pada kategori sangat kurang. Hanya 6\% yang berada dalam kategori sangat baik dan baik sedangkan $88 \%$ lainnya berada dalam kategori sangat kurang, dan kurang, 6\% lainnya berada dalam kategori cukup.

Sedangkan rata-rata kemampuan mahasiswa dalam menjawab nomor empat, yang berkaitan dengan menentukan suatu solusi umum persamaan diferensial ordo satu eksak, yaitu 73,438 dapat disimpulkan bahwa kemampuan mahasiswa berada pada kategori baik. Sebanyak 75\% mahasiswa berada dalam kategori sangat baik dan baik sedangkan hanya 19\% yang berada dalam kategori sangat kurang, dan kurang, 6\% lainnya berada dalam kategori cukup.

Selanjunya rata-rata kemampuan mahasiswa dalam menjawab nomor lima yang berkaitan dengan menentukan faktor integrasi dari persamaan diferensial ordo satu tidak eksak, yaitu 83,125 dapat disimpulkan bahwa kemampuan mahasiswa berada pada kategori baik. Sebanyak 94\% mahasiswa berada dalam kategori sangat baik dan baik sedangkan hanya $6 \%$ yang berada dalam kategori sangat kurang.

Adapun rata-rata kemampuan mahasiswa dalam menjawab nomor enam, yang berkaitan dengan menentukan suatu solusi khusus persamaan diferensial ordo satu peubah terpisah, yaitu 45,573 dapat disimpulkan bahwa kemampuan mahasiswa berada pada kategori sangat kurang. Hanya $28 \%$ yang berada dalam kategori sangat baik dan baik sedangkan 69\% lainnya berada dalam kategori sangat kurang, dan kurang, 3\% lainnya berada dalam kategori cukup.

Sedangkan rata-rata kemampuan mahasiswa dalam menjawab nomor tujuh yang berkaitan dengan menentukan suatu solusi umum persamaan diferensial ordo satu linear, 
yaitu 71,094 dapat disimpulkan bahwa kemampuan mahasiswa berada pada kategori baik. Sebanyak 75\% mahasiswa berada dalam kategori sangat baik dan baik sedangkan hanya $6 \%$ yang berada dalam kategori sangat kurang, sisanya 19\% cukup.

\section{Kesulitan yang Dihadapi Mahasiwa Pendidikan Matematika dalam Menyelesaikan Soal-Soal Kemampuan Penalaran Analogis}

Kesulitan-kesulitan yang dihadapi mahasiswa antara lain pada memeriksa sebuah persamaan adalah solusi khusus dari sebuah persamaan diferensial ordo satu. Mahasiswa kesulitan mengidentifikasi langkah-langkah melakukan pemeriksaan sebuah persamaan adalah solusi khusus dari sebuah persamaan diferensial ordo satu pada saat mengerjakan lembar kerja ketika perkuliahan sebagai domain dasar.

Mahasiswa juga kesulitan dalam menentukan solusi umum persamaan diferensial ordo satu peubah terpisah. Mahasiswa kesulitan melakukan pemetaan struktur bentuk persamaan diferensial ordo satu peubah terpisah ketika menemukan skema baru. Mahasiswa juga kesulitan mengidentifikasi langkah-langkah dalam menentukan solusi umum solusi umum persamaan diferensial ordo satu peubah terpisah.

Kemudian mahasiswa sangat kesulitan menentukan solusi umum persamaan diferensial homogen. Mahasiswa kesulitan membentuk skema dasar langkah-langkah menentukan solusi umum persamaan diferensial homogen kemudian harus menghubungkan dengan persamaan diferensial peubah terpisah.

Begitu juga mahasiswa sangat kesulitan dalam menentukan suatu solusi khusus persamaan diferensial ordo satu peubah terpisah. Mahasiswa kesulitan mengidentifikasi skema dasar persamaan diferensial ordo satu peubah terpisah sebagaimana ketika mereka mereka menjawab pada soal nomor 2 .

\section{KESIMPULAN}

Berdasarkan hasil penelitian dan pembahasan dapat disimpulkan bahwa,

1. Kemampuan penalaran analogis mahasiswa pendidikan matematika berada pada kategori sangat kurang pada dua soal, yaitu yang berkaitan dengan menentukan solusi umum dari sebuah persamaan diferensial ordo satu homogen dan menentukan solusi khusus dari sebuah persamaan diferensial ordo satu peubah terpisah. Kemudian pada kategori kurang pada dua soal, yaitu yang berkaitan dengan memeriksa sebuah persamaan adalah solusi khusus dari persamaan diferensial ordo 
satu. Sedangkan berada pada kategori baik pada tiga soal, yaitu menentukan solusi umum dari persamaan diferensial ordo satu eksak dan linear, serta menentukan faktor integrasi

2. Kesulitan mahasiswa yang dihadapi pada mengidentifikasi skema dasar bentuk persamaan diferensial ordo satu peubah terpisah dan homogen dan langkah-langkah penyelesaian yang dianggap rumit sehingga ketika berhadapan dengan skema baru mereka kesulitan. Kemudian juga yang terkaitan dengan menentukan solusi khusus dan memeriksa bahwa sebuah persamaan adalah solusi khusus dari sebuah persamaan diferensial, karena berhubungan dengan persamaan diferensial ordo satu peubah terpisah.

\section{REFERENSI}

Ball, L. J., Ormerod, T. C., \& Morely, N. J. (2004). Spontaneous analogising in engineering design: A comparative analysis of experts and novices. Design Studies, 25, 495-508.

Cambridge Dictionary. (Tanpa Tahun). Tersedia: dictionary.cambridge.org. Diakses: 23 Januari 2017

Cross, N. (1994). Engineering design methods: Strategies for product design. (2nd ed.) Chichester, England: John Wiley \& Sons.

Darsinah, dkk. (2013). Pedoman Penulisan Skripsi FKIP. Surakarta: Badan Penerbit-FKIP. Daugherty, Jenny and Mentzer, Nathan. (2008). Analogical Reasoning in the Engineering Design Process and Technology Education Applications. Journal of Technology Education Vol. 19 No. 2, Spring.

Gentner, D., \& Gentner, D. R. (1983). Flowing waters or teeming crowds: Mental models of electricity. In D. Gentner \& A. L. Stevens (Eds.), Mental models (pp. 99-129). Hissdale, NJ: Erlbaum.

Goldschmidt, G. (2001). Visual analogy: A strategy for design reasoning and learning. In C. Eastman, M. McCracken, \& W. Newstetter (Eds.), Design knowing and learning: Cognition in design education (pp. 199- 218). Amsterdam: Elsevier Science.

Haglund, Jesper. (2012). Analogical Reasoning in Science Education- Connections to Semantics and Scientific Modelling in Thermodynamics. The Swedish National Graduate School in Science and Technology Education (FontD), The Department of Social and Welfare Studies (ISV), Linköping University, S-60174 Norrköping Sweden.

Holyoak, K.J. (2012). Analogy dan Relational Reasoning dalam K.J. Holyoak \& R.G. Morisson (Eds). The Oxford Handbook of Thingking and Reasoning. New York: Oxford University Press.

Kamus Besar Bahasa Indonesia Online. (Tanpa Tahun). Tersedia: kbbi.web.id. Diakses: 23 Januari 2017

Kilpatrick J, Swafford J \& Findell B (eds.) 2001. Adding It Up: Helping Children Learn Mathematics. Washington, DC: National Academy Press. 
Merriam-Webster Learner's Dictonary. (Tanpa Tahun).Tersedia: learnersdictionary.com. Diakses: 23 Januari 2017

Merriam-Webster. (Tanpa Tahun).Tersedia: merriam-webster.com. Diakses: 23 Januari 2017

Magdaş, Ioana. (2015). Analogical Reasoning in Geometry Education. Acta Didactina Napocensia. Volume 8, Number 1.

Mofidi, Somayeh Amir, dkk. (2012). Instruction of Mathematical Concepts Through Analogical Reasoning Skills. Indian Journal of Science and Technology Vol. 5 No. 6.

National Council of Teachers of Mathematics (NCTM) 2000. Executive Summary: Principles and standards for school mathematics. Reston, VA: NCTM. Tersedia: https://www.nctm.org/uploadedFiles/Standards_and_Positions/PSSM_ExecutiveSu mmary.pdf. Diakses 16 April 2017.

Schlimm, Dirk. (2008). Two Ways of Analogy: Extending the Study of Analogies to Mathematical Domains. Philosophy of Science, Vol. 75, No. 2, The University of Chicago Press on behalf of the Philosophy of Science Association

Shadiq, Fadjar. (2013). Penalaran dengan Analogi? Pengertiannya dan Mengapa Penting?. Tersedia

http://p4tkmatematika.org/file/ARTIKEL/Artikel\%20Matematika/Penalaran\%20de ngan\%20analogi_fadjar\%20shadiq.pdf. Diakses : 18 Desember 2016.

Suherman, Erman dan Sukjaya, Yaya. (1990). Evaluasi Pendidikan Matematika. Bandung: Wijayakusumah. 